\title{
4. Holofernes's Canopy in the Septuagint
}

\author{
Barbara Schmitz
}

Judith beheads Holofernes - the provocative nature of the story related in the Book of Judith is immediately clear from this somewhat oversimplified summary of the biblical tale. The fact that a man is killed by a woman means that the story was, and sometimes still is, perceived as scandalous. A wide variety of models have been constructed to interpret Judith's shocking deed, including most notably in modern times the influential interpretations by Friedrich Hebbel and Sigmund Freud. ${ }^{1}$ Interestingly, however, the question of how we should understand Judith's deed is not only one for the later reception of the story, but in fact forms a theme of the biblical story itself. This paper will analyze the construction of the figure and role ${ }^{2}$ of Holofernes, with a special emphasis on the meaning and function of an apparently small detail of the story, the $\kappa \omega \nu \omega \dot{\pi} \pi \mathrm{ov}$.

Holofernes appears in the story for the first time in the second chapter (Jdt 2:4) as commander-in-chief of the Assyrian troops. He is instructed by the Assyrian king, Nebuchadnezzar, to conquer the people in the West (Jdt 2:5-13). Judith, who appears later, is introduced and described in detail (Jdt 8:1-8), but Holofernes receives no such treatment and is instead simply characterized through his actions.

1 Friedrich Hebbel, Judith. Eine Tragödie in fünf Akten (Stuttgart: 1980 [1839/40]); Sigmund Freud, "Das Tabu der Virginität," in Ders. Studienausgabe V. Sexualleben (Frankfurt a.M.: Fischer, 1972), pp. 211-28; see also Sigmund Freud, "Über die weibliche Sexualität," in Ders. Studienausgabe V. Sexualleben (Frankfurt a.M.: Fischer, 1972), pp. 273-92.

2 Cf. Barbara Schmitz, "Casting Judith: The Construction of Role Patterns in the Book of Judith," in Hermann Lichtenberger and Ulrike Mittmann-Richert (eds.), Biblical Figures in Deuterocanonical and Cognate Literature. International Conference of the ISDCL at Tübingen. Yearbook of the International Society for the Study of Deuterocanonical and Cognate Literature 2008 (Berlin: Walter de Gruyter, 2009), pp. 77-94. 

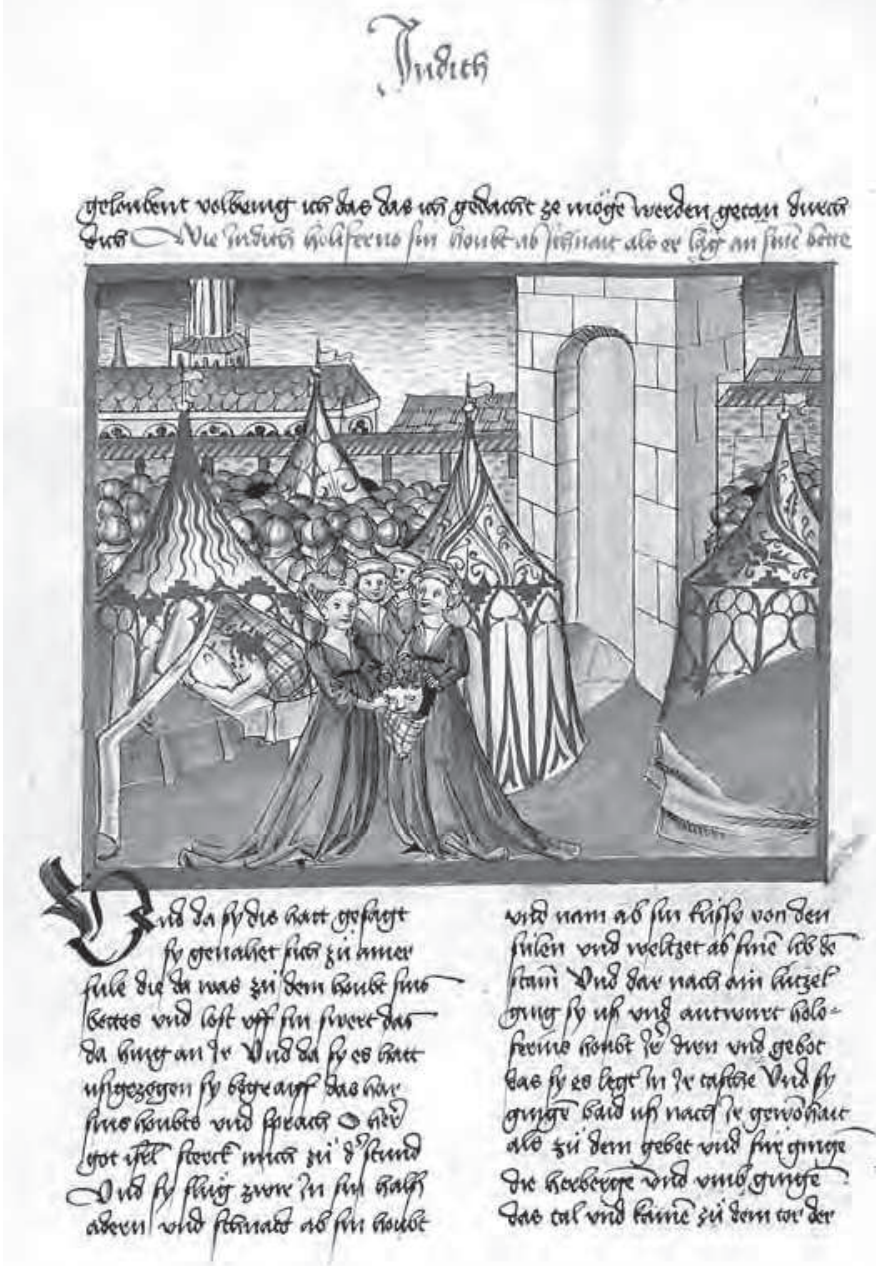

Workshop of Ludwig Henfflin, German Bible, ca. 1479. Heidelberg University Library, Cpg 17, fol. 255v. Photo credit: Heidelberger historische Bestände - digital (http://diglit.ub.uni-heidelberg.de/)

Holofernes is loyal to his king; he follows Nebuchadnezzar's instructions for conscription and equipping the troops to the letter and simultaneously proves his own military expertise (Jdt 2:14-20). The description of the military preparations focuses solely on Holofernes: he personally levies the various troops, provides them with a leadership structure, and ensures the provision of food and equipment. Holofernes the general is thus characterized as a highly effective man. Even in the depiction of the 
military campaign by the Assyrian troops, the action is focused entirely on Holofernes (Jdt 2:22-27; cf. Jdt 7:6-7): He conquers territories, crosses rivers, plunders, steals, and destroys. This description draws in many respects on apocalyptic texts that address the themes of the Day of Judgment and the Day of JHWH (cf. Jer 25:32; Am 1-2; Jl). The horror brought by the Assyrian army is thus personified by the violent, brutal, and ruthless Holofernes, who further demonstrates his power by his destruction of temples and his call for the veneration of Nebuchadnezzar as the only God (Jdt 3:8).

In the first part of the story, Holofernes is therefore portrayed as a successful commander and quintessentially male hero. Yet the later portrayal of Holofernes is quite different and stands in sharp contrast to the characterization at the beginning. ${ }^{3}$ The second part of the story (Jdt 8-16) begins with the newly introduced figure of Judith, who remains the focus for the rest of the action (Jdt 8-9). This beautiful, rich widow has heard that the residents of Bethulia, who are on the verge of starvation after being besieged by the Assyrian troops for weeks on end, now want to open the city gates and surrender to Holofernes. This would not only mean the military capitulation of a small city, but would also clear the way for the Assyrians to advance on and conquer Jerusalem, resulting in the submission of Israel to King Nebuchadnezzar, whom the Jews would have to worship as a god (cf. Jdt 3:8; 6:2). Because of the disastrous consequences of a surrender on the part of Bethulia, Judith rebukes the elders of the city who have negotiated a five-day ultimatum with the people. She reflects on the theological implications and consequences of the surrender of the city (Jdt 8) and then announces her intention of carrying out an unspecified act (Jdt 8:32-34). After praying (Jdt 9), Judith prepares for her task, leaves the city, and goes into the Assyrian camp (Jdt 10).

Holofernes does not appear again as an active protagonist until Jdt 10:20. In fact, in the second part of the book (Jdt 8-16), he is only present in Jdt 10:20-12:20; after his assassination (Jdt 13:8) his head and decapitated body are merely used as props.

A key difference between the first and second parts of the story is the construction of space in the latter part: Judith, the woman who leaves the protected space of her house and moves to a place where she is in mortal danger in the camp of the Assyrians, stands in contrast to Holofernes, the man who has now withdrawn into the private, intimate sphere of his

3 The Book of Judith is divided into two parts in the Septuagint (Jdt 1-7; 8-16); this division is crucial for the contrasting portrayal of Holofernes in each part. 


\section{Barbara Schmitz}

interior rooms at the camp. The general, who in the first part stands as the representative of the entire army and is portrayed as a highly successful military operator, is now described in isolation as a private man, whose life and living environment is fundamentally different from that of his soldiers.

The reader only becomes acquainted with Holofernes's living conditions in the camp in the course of the description of the first meeting between Judith and Holofernes, in which Judith succeeds in winning the general's confidence (Jdt 11) and so is able to put her plan into action. Because Judith meets Holofernes this first time not in his tent but in the awning (Jdt 10:22), the first meeting between the two takes the form of each approaching the other: Judith is led into the awning by Holofernes's servants (Jdt 10:20), while Holofernes enters in an almost liturgical procession (Jdt 10:22). Between these two movements is a short, but crucial description of the décor and furnishings of the main tent (Jdt 10:21), which Judith will enter for the first and only time later on for the meal (Jdt 12:16; 13:2) in his tent, the commander, who until now has been portrayed as quintessentially masculine and heroic, is lying on his bed ${ }^{4}$ under a purple

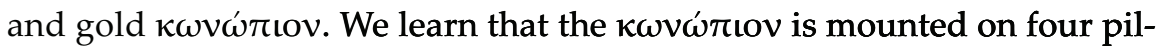
lars and spans the entire bed, and that it is adorned with emeralds and other precious stones (cf. Jdt 13:9).

The $\kappa \omega \nu \omega ́ \pi$ tov is a highly interesting detail of the narrative and is mentioned four times in total: once in chapter 10, twice in chapter 13, and once again in chapter 16 (Jdt 10:21; 13:9, 15; 16:19). As already mentioned, when Judith first encounters Holofernes in chapter 10, he is lying on his bed. This bed is draped with a $\kappa \omega \nu \omega t \leftarrow$ tov woven of purple and gold, adorned with emeralds and precious stones (Jdt 10:21). After the murder in chapter 13, Judith pulls the net off of the bed, wraps the severed head in it, and takes it with her to show as a trophy in Bethulia (Jdt 13:15). At the end of the story Judith hands over Holofernes's belongings to the temple in Jerusalem (Jdt 16:19), and the $\kappa \omega \nu \omega ́ \pi เ o v$ is explicitly mentioned in this context in chapter $16 .{ }^{5}$

It has often been claimed that the four-fold repetition of the word $\kappa \omega \nu \omega \dot{\pi}$ เov is "highly symbolic," ${ }^{6}$ but what exactly is the significance of the

4 Holofernes's bed is an important motif in the story ( $\kappa \lambda$ ív $\eta$ in Jdt 10:21; 13:2, 4 , 6, 7; 15:11 and $\sigma \tau \varrho \omega \mu \nu \eta$ in Jdt 13:9): with the change of the $\kappa \lambda$ ív $\eta$ to the word $\sigma \tau \varrho \omega \mu \nu \eta \dot{~ i n ~ t h e ~ m u r d e r ~ s c e n e ~ i n ~ t h e ~ s t o r y ~ w h e n ~ D i n a ~ i s ~ r e m a n d e d ~(J d t ~ 9: 3), ~ b u t ~ a l s o ~}$ in the Book of Amos (Am 6:4).

5 Thereby Judith fulfills her promise to Holofernes in Jdt 11:19: by carrying his head in his mosquito net she has indeed led him to Jerusalem and set up a throne for him in the middle of the city.

6 Erich Zenger, "Das Buch Judit," Jüdische Schriften aus hellenistisch-römischer Zeit 1 
motif and what does it represent? No satisfactory answer has yet been found and the search for the meaning of the $\kappa \omega \nu \omega t \pi$ ov is indeed a difficult task. ${ }^{7}$

The quest begins with the term itself: the Greek word $\kappa \omega \nu \omega \dot{\omega}$ เov is derived from the Greek word $\kappa \omega \omega \omega \omega \psi$, meaning "mosquito," so $\kappa \omega \nu \omega \dot{\pi} t \mathrm{tov}$ means "mosquito net." 8 Despite its costly adornments, the $\kappa \omega v \omega ́ \pi$ tov must be a light net since Judith's companion can carry it and its contents unnoticed out of the Assyrian camp. The word $\kappa \omega v \omega \pi t o v$ has been translated to Latin as conopeum, again meaning "mosquito net." The word canapeum has made its way into the European languages via medieval Latin. In French and German, it no longer means a mosquito net, but instead a sofa. ${ }^{9}$

Other written sources shed no new light on the term $\kappa \omega \nu \omega t ı v$. The word $\kappa \omega \nu \omega t \pi$ เov cannot be found anywhere in the Bible, in ancient Middle Eastern texts, or in Greek literature. Likewise, the word $\kappa \omega v \omega \pi$ เov does not occur in archaeological sources. The only mention is found in Herodotus, who reports on stinking fishing nets used to deter mosquitoes in Egypt (Hdt II 95). Clearly, however, there are worlds between stinking fishing nets and Holofernes's costly $\kappa \omega \nu \omega \dot{\tau} \leftarrow \circ v$, and so this brief note is of no help.

The canopy is first mentioned in Roman times, more specifically during the rule of Augustus. An investigation into Latin literature dating from the first century в.С.E. ${ }^{10}$ has produced three pieces of evidence about the conopeum. (JSHRZ I/6), (Gütersloh: G. Mohn, 1981), p. 498.

7 Cf. Art. "Konopeion," in August Pauly, Georg Wissowa, Wilhelm Kroll et al. (eds.), Paulys Realencyclopädie der classischen Altertumswissenschaft, vol. 22 (Stuttgart: J.B. Metzler, 1894-1980 [1922]), pp. 1341-42; Rolf Hurschmann, "Konopion," in Hubert Cancik and Helmuth Schneider (eds.), Der neue Pauly. Enzyklopädie der Antike. Das klassische Altertum und seine Rezeptionsgeschichte, vol. 6 (Stuttgart: J.B. Metzler, 1996-[1999]), p. 709; Wolfgang Helck, "Moskitonetze," in Lexikon der Ägyptologie, vol. 4 (1982), pp. 211-12.

8 Henry George Liddell and Robert Scott, A Greek-English Lexicon (Oxford, 1889; reprint: New York and Oxford: Oxford University Press, 2000), p. 460.

9 Cf. Art. "Mücke," in Paulys Realencyclopädie der klassischen Altertumswissenschaft, vol. 31 (1933), pp. 450-54; Karl Ernst Georges, Lateinisch-Deutsches Handwörterbuch (Darmstadt: Nachdruck, 1918), pp. 1494-787; Christian Hünemörder, “Mücke," in Der neue Pauly, vol. 8 (2000), pp. 429-30. The Greek word was taken into Aramaic as qinuf and means "net," but also "frame" in the Talmudic sources, cf. Mishnah Sukkah i, 3; Babylonian Talmud Sukkah 10a-b; Babylonian Talmud Sanhedrin 68a; Tosefta Kelim Babva Metzia ii,8. The most interesting variant is qinufi, meaning "a curtained couch," which appears in the Aramaic Targum to 2 Sm 16:22 as a translation of the Hebrew ohel, a tent; cf. Marcus Jastrow, Dictionary of Targumim, the Talmud Babli and Yerushalmi, and the Midrashic Literature ([Repr. der Ausg.] New York: Title Publ., 1943, repr. Peabody, MA: Hendrickson, 2005), p. 1363. For this information, thanks are due to Dr. Susan Weingarten.

10 Cf. also the motif of the Canopy in Juvenal's Satires (Sat. 6, 78-81) originating after 100 c.E.; cf. Ludwig Friedländer, D. Junii Juvenalis. Saturae XIV (Leipzig: S. 


\section{Barbara Schmitz}

Horace and Propertius both use the motif in the context of the description of Octavian's victory in 31 в.с.E. against Antony and Cleopatra. In both cases the canopy functions as a symbol of Cleopatra, who is depicted as a femme fatale.

1. Horace (epodes 9, 16; 65-8 в.с.в.) ${ }^{11}$ describes Cleopatra as an "emancipated woman,"12 who is counseled by eunuchs. A eunuch connotes a strong contrast to a free Roman citizen, whose ideal is virility and virtue. Cleopatra's reign is understood as a "perversion" of the order of society and is presented as symptomatic of the sharp contrast between the western and the eastern world. The symbol of her reign is a "disgraceful mosquito net" that Horace presents as a "disgusting" symptom of oriental effeminacy. ${ }^{13}$

2. Propertius (50/45-15 в.с.E.) also uses the motif of the canopy in his elegies (elegies 3, 11, 45; 29-15 в.C.E.). ${ }^{14}$ He describes a series of powerful women, culminating with Cleopatra. In a horror scenario, he describes how Cleopatra imposes her rule on the Capitol in Rome and spans out her "disgraceful mosquito net" $(9,45)$. The canopy is presented as the strongest possible contrast to Roman culture and as a luxurious item, which stands for an unthinkable disaster: Cleopatra under her canopy as ruler on the Roman Capitol, the very center of Roman identity.

Hirzel, 1895), pp. 294-95; Edward Courtney, A Commentary on the Satires of Juvenal (London: The Athlone Press, 1980), pp. 272-73; Joachim Adamietz, Juvenal, Satiren (Sammlung Tusculum) (Munich: Artemis \& Winkler, 1993), pp. 358-59.

11 For the following interpretation of the ninth epode of Horace cf. Egil Kraggerud, Horaz und Actium. Studien zu den politischen Epoden (Oslo: Universitetsforlaget; Irvington-on-Hudson, NY: Distribution, Columbia University Press, 1984), pp. 66-128; Georg Maurach, Horaz. Werk und Leben (Wissenschaftliche Kommentare zu griechischen und lateinischen Schriftstellern) (Heidelberg: Universitätsverlag C. Winter, 2001), pp. 40-43.

12 emancipatus feminae: Emancipare is a rare and technical word and is only used here by Horace; cf. David Mankin (ed.), Horace. Epodes (Cambridge Greek and Latin Classics) (Cambridge: Cambridge University Press, 1995), p. 166; cf. Robert H. Brophy, "Emancipatus Feminae: A Legal Metaphor in Horace and Plautus," Transactions and Proceedings of the American Philological Association (TPAPA), vol. 105 (1975), pp. 1-11.

13 Daniel H. Garrison, Horace. Epodes and Odes. A New Annotated Latin Edition, Oklahoma Series in Classical Culture, vol. 10 (1991), p. 184.

14 Cf. Max Rothstein, Die Elegien des Sextus Propertius, vol. 2 (Berlin: Weidmann, 1924), pp. 94-96; Harold E. Butler and Eric A. Barber, The Elegies of Propertius (Oxford: Clarendon Press, 1933), pp. 290-91; W. A. Camps (ed.), Propertius Elegies, vol. 3 (Cambridge: Cambridge University Press, 1966), p. 108; Burkhard Mojsisch, HansHorst Schwarz, and Isabel J. Tautz, Sextus Propertius. Sämtliche Gedichte (Stuttgart: Reclam, 1993), pp. 208-09. 


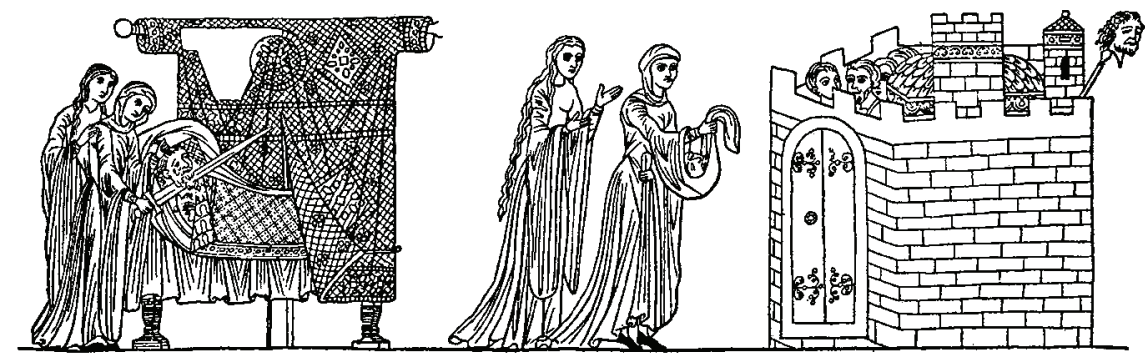

Herrad of Hohenbourg, Hortus Deliciarum, fol. 60r, 1167-85. Photo credit: Green II, p. 99.

3. Varro (116-27 в.С.Е.), a contemporary of Horace and Propertius, mentions the use of a canopy by a Roman upper class woman who is giving birth; it is therefore presented as despicable, feminine item (Varro, r.r. 2, 10, 8). ${ }^{15}$

Even though these texts from Latin literature are quite different, there is a remarkable similarity in the way they present the canopy: in each case, it is an attribute of women and represents a devotion to luxury and the life style of high society. At the same time it symbolizes women having power over men. In the narrative of Judith, however, the $\kappa \omega v \omega t i o v$ is an attribute of the man Holofernes, the despotic Lord of the East, who threatens the freedom and religious identity of Western nations and Israel. In the second part of the story, the $\kappa \omega v \omega \dot{\omega}$ เov serves to make Holofernes appear as a far more effeminate, weakened figure than at the beginning, and opens up an interesting gender perspective in the portrayal of Holofernes in two respects. Firstly, he is a man who surrenders himself to the beautiful Judith; although she says that she is his slave (Jdt 11:5, 16, 17), she in fact makes him her victim. Secondly, as he lies under the $\kappa \omega v \omega \dot{\pi} \iota \mathrm{ov}$, he is characterized, in very strong terms that are suggestive of cross-gendering, as feminine. Holofernes is portrayed as womanlike and as having deficient masculinity. This is evident even in his reply to Judith's speech: Holofernes replies by quoting a woman when he uses the words of Ruth (Jdt 11:23, cf. Ru 1:6).

Despite these suggestions of femininity in the portrayal of Holofernes, he does continue to figure as a male hero in other respects. He instructs Bagoas to arrange "contact" with Judith without specifying his exact

15 Dieter Flach (ed. and trans.), Marcus Terentius Varro, Gespräche über die Landwirtschaft, vol. 2 (Texte zur Forschung 66) (Darmstadt: Wissenschaftliche Buchgesellschaft, 1997). 


\section{Barbara Schmitz}

wishes (ó $\mu \iota \lambda \varepsilon \omega^{16} ;$ Jdt 12:12). His intentions are in fact perfectly clear, since he is worried that he will be a laughingstock if he fails to have "contact" with this beautiful woman. It seems that the ambiguity of his formulation $\kappa \alpha \tau \alpha \gamma \varepsilon \lambda \alpha \dot{\alpha} \sigma \varepsilon \tau \alpha$ เ (third-person singular) is intentional: this word can be either the feminine form of the verb "she would laugh" or the impersonal form "one would laugh." In accordance with Holofernes's wishes, Bagoas organizes a meal to which Judith is invited. When Judith appears for the meal she has adorned herself, and Holofernes is captivated by her beauty and filled with desire. In order to achieve his goal, he invites Judith to drink, yet ironically this is what brings about his own downfall (Jdt 12:17). While he hopes the alcohol will make Judith obtainable, his own indulgence in alcohol in fact makes him vulnerable to her (Jdt 12:20). In his intoxication, the aggressive conqueror drops completely defenseless onto his bed, which is draped with the $\kappa \omega \nu \omega ́ \pi เ \mathrm{v}$ (Jdt 13:2). Judith is now able to kill Holofernes

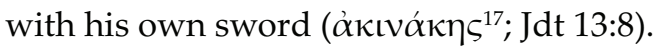

In the meeting with Judith, Holofernes is in a weak position and loses control of his actions, whereas Judith maintains complete sovereignty of her actions throughout. The fact that the positions of power are exchanged in this way means that the story of Judith, on one level, is a strategic play on established gender roles and the showcasing of an intelligent woman. That Judith's deed is possible at all, however, is due neither to the cunning of Judith nor to the carelessness of Holofernes, but rather finds its explanation on a theological level. ${ }^{18}$ Behind the exciting story line, the speeches and prayers in the Judith story contain a deeper level of theological reflection, and the events being recounted receive a theological basis and interpretation. It is clear, for example, that Judith's actions are not guided by emotion, but rather that she interprets her deed as God's action through her hands. By murdering this one person, she aims to save Israel and the whole of the Western world from the threat of the Assyrians (Jdt 13:14, 15; 16:5). After Judith's deed, the decapitated corpse of Holofernes lies in the tent, while

16 The verb ó $\mu \lambda \varepsilon^{\prime} \omega$ means "to have dealings with somebody" or "to entertain oneself" (Dn 1:19), but can also be used to mean "sexual contact"; the last meaning occurs in the context of power and rape (cf. Sus. 1:37, 57, 58). Cf. the intertextual network involving $\dot{\varepsilon} \pi \iota \sigma \pi \alpha$ o $\mu \alpha$ เ in the context of the sexual activities of Potiphar's wife (Gn 39:12).

17 The word $\dot{\alpha} \kappa \iota v \alpha ́ \kappa \eta \varsigma$ describes a small, sharp Persian sword; cf. Herodotus 7,54:

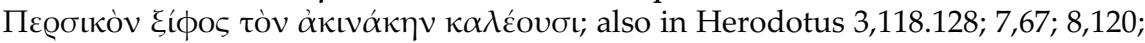
Horace Odes 1,27,5. Cf. the story of David and Goliath, in which Goliath was killed by his own sword (1 Sm 17:51).

18 Cf. Barbara Schmitz, Gedeutete Geschichte. Die Funktion der Reden und Gebete im Buch Judit (Herders Biblische Studien (HBS) vol. 40) (Freiburg: Herder, 2004). 
his mighty army is unaware of his fate. Judith and her maid manage to escape to Bethulia, taking Holofernes's head and the $\kappa \omega v \omega \pi$ tov as a trophy and evidence of their act. The head of Holofernes is later hung as a symbol of the victory on the city walls of Bethulia (Jdt 14:1, 11). ${ }^{19}$

Yet the story of the $\kappa \omega \nu \omega t \pi$ tov does not end here; it is mentioned again a final time at the end of the story (Jdt 16:19). After looting the Assyrian camp, the people give the most important items they have plundered from Holofernes's tent to Judith, and she donates these items to the temple in Jerusalem (Jdt 16:19). This custom of consecrating property or people to make a holy relic was widespread throughout the ancient world, and was meant to make the spoils of war taboo (for the purposes of destruction or

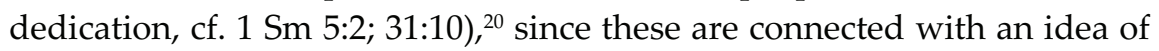
religiosity that is materialistic and contaminated (cf. Jo 6:19; Lv 27:28; Nm 18:14). Interestingly, in addition to a brief reference to the plunder, there is an explicit mention of the $\kappa \omega \nu \omega \pi t o v$ in this context.

Thus, the story ends with Holofernes's $\kappa \omega \nu \omega \pi t \mathrm{ov}$. By handing it over to the temple in Jerusalem, Judith fulfils the pledge she made in her speech to Holofernes, when she promised to bring him to Jerusalem and set up a throne for him in the middle of the city (Jdt 11:19): While Holofernes's torso is left in the Assyrians' camp and his head is displayed on the city wall, his $\kappa \omega \nu \omega \dot{\omega} \iota \mathrm{ov}$, together with the rest of the loot, is handed over to the temple in Jerusalem. The handing over of the $\kappa \omega v \omega \pi$ เov marks the climax and the end of the story.

Whereas the first part of the story presents Holofernes in ideal terms as a successful man and brave soldier, the second part of the story in contrast stresses precisely his femininity. The narrative explicitly stages this by contrasting the expectations placed on Holofernes in the first and second parts. The soldiers reserve Judith for Holofernes (Jdt 10:15, 19) and so perpetuate the image of the potent general from the first part of the story. Holofernes discusses with his servant, the eunuch Bagoas, the masculine pressure to perform with Judith (Jdt 12:11, 12). He speculates about a sexual adventure, in which he will seduce the beautiful Judith, or failing this, "take" her by force if necessary. Yet the Holofernes of the second part of the story is not in a position to perform with Judith (Jdt 12:16), but instead succumbs in his anticipation in a wholly unmanly way to a self-inflicted alcoholic delirium. In this way, Holofernes mutates in his meeting with Judith from a brave

19 Cf. 1 Mc 7:47; 2 Mc 15:35; cf. also 1 Sm 31:10.

20 Cf. Art. "Avá $\theta \varepsilon \mu \alpha$," in Der neue Pauly, vol. 2 (Stuttgart, 1894), p. 2069; Norbert Lohfink, Neues Bibel Lexikon, vol. 1 (Zürich, 1991), p. 238. 
soldier and a hero confident of success into an excessive drinker, lacking in self-control (Jdt 12:20; 13:2). The indulgent Holofernes at the end of the story stands in sharp contrast to the ideal of the "masculine" warrior who lives in harsh, spartan conditions (cf. e.g. 2 Sm 11:11).

While Judith is a metaphor for the Jewish community and stands for the concept of "community formation," ${ }^{21}$ Holofernes embodies a development in the opposite direction. At the beginning he represents the whole army, Ashur and King Nebuchadnezzar, but at the end all that remains is a dispersing army and its slain commander, whose severed head has become the trophy of his enemies and whose destructive power is now itself completely destroyed. This development is made clear through the recurrent $\kappa \omega v \omega \dot{\omega} \pi \mathrm{L}$ motif: because of his association with the $\kappa \omega v \omega \dot{\omega} \pi \mathrm{L}$, Holofernes appears effeminate, even before he meets Judith, and by using the terminology of cross-gendering he is characterized through the $\kappa \omega \nu \omega \pi t o v$ as feminine. The heroic and virile general is described as a weak man. In contrast to the characterization of Holofernes in the first part of the narrative as an ideal warrior, bold and successful, the second part emphasizes his unmanliness. During the confrontation with Judith, he gives in to alcohol in his thrill of anticipation and thereby becomes powerless and impotent in a very unmanly way. The story reveals that Holofernes, the brave man and hero, is defeated by a woman because he has become a soft and effeminate man.

A reading of the Latin literature which contains the conopeum motif serves to illuminate the meaning and function of the $\kappa \omega v \omega \pi \mathrm{t} \iota v$ in the story of Judith. The construction of gender roles in the Book of Judith does not in fact subvert these roles, but rather reinforces them in their patriarchal connotation. Ultimately, therefore, the story of Judith offers a truly patriarchal explanation for the scandalous fact that a woman, however God-fearing she may be, is able to kill a man.

21 Amy-Jill Levine, "Character Construction and Community Formation in the Book of Judith," in Athalya Brenner (ed.), A Feminist Companion to Esther, Judith and Susanna (Sheffield: Sheffield Academic Press, 1995), pp. 561-69. 